\title{
Functional Change of NMDA Receptors Related to Enhancement of Susceptibility to Neurotoxicity in the Developing Pontine Nucleus
}

\author{
Akira Mitani, ${ }^{1}$ Masahiko Watanabe, ${ }^{2}$ and Kiyoshi Kataoka ${ }^{1}$ \\ ${ }^{1}$ Department of Physiology, School of Medicine, Ehime University, Shigenobu, Onsen-gun, Ehime 791-0295, Japan, and \\ 2Department of Anatomy, Hokkaido University School of Medicine, Sapporo 060-8638, Japan
}

\begin{abstract}
The developing neurons have been reported to be extremely susceptible to toxicity of NMDA during a restricted developmental period. Pontosubicular neuronal necrosis is a typical type of perinatal human brain lesion and often coexists with other forms of cerebral hypoxic and ischemic injuries. To determine whether functional changes of NMDA receptors related to the susceptibility to NMDA toxicity are involved in developing neurons in the pontine nucleus, we have examined the lesion produced by in vivo direct injection of NMDA into the pontine nucleus of rats at postnatal days 1-30, recorded NMDAinduced whole-cell currents from neurons in the pontine nucleus in the developing rat brainstem slices, and performed in situ hybridization for NMDA receptor subunit mRNAs in the pontine nucleus. The susceptibility to NMDA neurotoxicity peaked near postnatal day 15, and the NMDA-induced currents
\end{abstract}

showed prominent reduction of the voltage-dependent block by $\mathrm{Mg}^{2+}$ near postnatal day 15 . The pontine nucleus near postnatal day 15 showed distinct expression of the NMDA receptor subunit NR2C mRNA. These results suggest that the susceptibility to NMDA neurotoxicity that is enhanced in the rat pontine nucleus near postnatal day 15 is mediated by the NMDA receptor channels that are relatively insensitive to $\mathrm{Mg}^{2+}$ and that the reduction in the sensitivity of NMDA receptors to $\mathrm{Mg}^{2+}$ correlates with the expression of the NR2C. We present the possibility that functional changes in the NMDA receptor channels play a crucial role in the occurrence of developmentally specific neuronal injury.

Key words: NMDA receptor; pontine nucleus; development; neurotoxicity; slice patch clamp; $\mathrm{Mg}^{2+}$ block; in situ hybridization; NR2 subunits
NMDA receptors play an important role in neuronal plasticity (Collingridge and Bliss, 1987; Mayer and Westbrook, 1987; Rabacchi et al., 1992; Komuro and Rakic, 1993). Recent molecular biological studies have revealed that marked changes occur in the distribution of mRNAs encoding various NMDA receptor subunits during development of the brain (Moriyoshi et al., 1991; Meguro et al., 1992; Watanabe et al., 1992; Yamazaki et al., 1992; Akazawa et al., 1994) and that the changes result in the appearance of functionally distinct NMDA receptors (Ikeda et al., 1992; Kutsuwada et al., 1992; Money et al., 1992, 1994; Ishii et al., 1993; Farrant et al., 1994; Sakimura et al., 1995; Takahashi et al., 1996). The developing brain has been reported also to be extremely susceptible to neurotoxicity produced by NMDA during a restricted developmental period (McDonald et al., 1988; McDonald and Johnston, 1990). These results may indicate that the functional changes of NMDA receptors underlie the NMDA neurotoxicity enhanced during a restricted developmental period.

Pontosubicular neuronal necrosis is a typical type of perinatal brain lesion (Friede, 1972). It often coexists with other forms of cerebral hypoxic and ischemic injuries and is found in the pontine nucleus and the subiculum of the hippocampus in the human

Received Dec. 22, 1997; revised July 17, 1998; accepted July 17, 1998.

This work was supported by research grants from the Mother and Child Health Foundation, the Ministry of Education, Science, and Culture of Japan, and the Ministry of Health and Welfare of Japan. We thank Dr. Tomoyuki Takahashi (Institute for Brain Research, University of Tokyo), Dr. Seiji Ozawa (Department of Physiology, Gunma University), and Dr. Youngnam Kang (Department of Physiology, Kyoto University) for critical advice. We also thank Mr. Takeo Yagi for photographic help and Mr. Manabu Miyoshi for help in the animal experiments.

Correspondence should be addressed to Dr. Akira Mitani, Department of Physiology, School of Medicine, Ehime University, Shigenobu, Onsen-gun, Ehime 7910295, Japan.

Copyright (C) 1998 Society for Neuroscience $\quad 0270-6474 / 98 / 197941-12 \$ 05.00 / 0$ brain during a restricted developmental period between 30 weeks of gestation and the second postnatal month (Friede, 1972; Torvik et al., 1992; Sohma et al., 1995). These clinical reports suggest the possibility that some functional changes of NMDA receptors are involved in neurons in the pontine nucleus and the subiculum during the restricted developmental period. The purpose of this study is to find the functional changes of NMDA receptors that are related to the susceptibility to NMDA toxicity in neurons of the pontine nucleus (PN neurons) during development. First, to determine whether changes in the susceptibility to NMDA neurotoxicity is involved in the developing pontine nucleus, we have examined the extent of the lesion produced by in vivo direct injection of NMDA into the developing pontine nucleus of the rat. Second, to determine what functional changes of NMDA receptors mediate the changes in the susceptibility to NMDA neurotoxicity, we have recorded whole-cell currents induced by NMDA from PN neurons of developing rat brainstem slices. Third, to clarify the molecular basis for the functional changes of NMDA receptors, we have performed in situ hybridization for NMDA receptor subunit mRNA expression with ${ }^{35} \mathrm{~S}$-dATP-labeled antisense oligonucleotides in the brainstem including the pontine nucleus.

According to histogenetic studies (Rakic and Sidman, 1970; Sidman and Rakic, 1982), mossy fibers of the pontine nucleus make contact with granule cells of the cerebellar cortex by $\sim 30$ weeks of gestation in the human. This stage approximately corresponds to the second postnatal week of the rat in which pontine mossy fibers begin to form synaptic connections with granule cells at postnatal days 10-12 (Altman, 1972a,b; Shimono et al., 1976). Therefore, in the present study, we have used rats at postnatal days $1-30$. 


\section{MATERIALS AND METHODS}

The following experiments were conducted in accordance with the Guideline for Animal Experimentation at Ehime University School of Medicine.

In vivo injection of $N M D A$. To examine developmental changes in neuronal susceptibility to the toxicity produced by NMDA, we injected NMDA in the pontine nucleus of Sprague Dawley rats at postnatal days 5-7 (P5-P7) $(n=18)$, at P14-P16 $(n=18)$, at P20-P21 $(n=18)$, and at P28-P30 $(n=18)$. P1 was designated as the day of birth. The animals were anesthetized with a mixture of $2.5 \%$ halothane in nitrous oxide/ oxygen (7:3). Micropipettes (tip diameter, 50-60 $\mu \mathrm{m}$ ) were pulled from thin-walled glass (105G; Drummond Scientific Company, Broomall, PA) and equipped with a stainless steel plunger (105P; Drummond Scientific Company) and a micrometer. The micropipettes were filled with $0.1,0.5$, or 1.0 mM NMDA (Sigma, St. Louis, MO) dissolved in a Ringer's solution, adjusted to $\mathrm{pH}$ 7.4. Stereotaxic pressure injections (total volume, $1 \mu \mathrm{l}$; $0.04 \mu \mathrm{l} / \mathrm{min}$ for $25 \mathrm{~min}$ ) were made into the pontine nucleus of rats at P5-P7 $(n=6,0.1 \mathrm{mM} \mathrm{NMDA} ; n=6,0.5 \mathrm{mM} \mathrm{NMDA}$; and $n=$ 6, $1.0 \mathrm{~mm}$ NMDA), at P14-P16 ( $n=6,0.1 \mathrm{~mm} \mathrm{NMDA} ; n=6,0.5 \mathrm{~mm}$ NMDA; and $n=6,1.0 \mathrm{~mm}$ NMDA), at P20-P21 ( $n=6,0.1 \mathrm{~mm} \mathrm{NMDA}$; $n=6,0.5 \mathrm{mM} \mathrm{NMDA}$; and $n=6,1.0 \mathrm{mM} \mathrm{NMDA})$, and at P28-P30 ( $n=$ 6, $0.1 \mathrm{~mm}$ NMDA; $n=6,0.5 \mathrm{~mm}$ NMDA; and $n=6,1.0 \mathrm{~mm}$ NMDA); injections were $0.2 \mathrm{~mm}$ rostral to lambda, $0.5 \mathrm{~mm}$ lateral to the midline, and $6.5 \mathrm{~mm}$ ventral to the cortical surface in $\mathrm{P} 5-\mathrm{P} 7$ rats; $0.2 \mathrm{~mm}$ rostral to lambda, $0.5 \mathrm{~mm}$ lateral to the midline, and $9.0 \mathrm{~mm}$ ventral to the cortical surface in $\mathrm{P} 14-\mathrm{P} 16$ rats; $0.1 \mathrm{~mm}$ rostral to lambda, $1.0 \mathrm{~mm}$ lateral to the midline, and $9.0 \mathrm{~mm}$ ventral to the cortical surface in P20-P21 rats; and $0.1 \mathrm{~mm}$ rostral to lambda, $1.0 \mathrm{~mm}$ lateral to the midline, and $9.6 \mathrm{~mm}$ ventral to the cortical surface in P28-P30 rats. Equivalent volumes of a Ringer's solution were injected into the pontine nucleus of control animals ( $n=2, \mathrm{P} 5-\mathrm{P} 7$ rats; $n=2, \mathrm{P} 14-\mathrm{P} 16$ rats; $n=2, \mathrm{P} 20-\mathrm{P} 21$ rats; and $n=2, \mathrm{P} 28-\mathrm{P} 30$ rats). After injections, the micropipettes were gently pulled out, and surgical incisions were carefully sutured. Rats were treated with antibiotics and brought into a comfortable position on a warming blanket. After awakening, rats at P5-P7 and P14-P16 were returned to their mothers, and rats at P20-P21 and $\mathrm{P} 28-\mathrm{P} 30$ were returned to individual cages. After $4 \mathrm{~d}$ of survival, the animals were deeply anesthetized with sodium pentobarbital and transcardially perfused with $10 \%$ formalin in $0.1 \mathrm{~m}$ phosphate buffer, $\mathrm{pH}$ 7.4. The brains were removed and saturated with a solution of $25 \%$ sucrose in the same buffer. Subsequently, frontal frozen sections were made serially at $40 \mu \mathrm{m}$ for Nissl stain. The serial sections of the pontine nucleus were scanned to determine which section contained the largest lesion, and the longest axis of the lesion was evaluated as the extent of the lesion produced by NMDA neurotoxicity.

In addition, to confirm that the lesion elicited by NMDA injection is attributable to NMDA receptor stimulation, we injected $1 \mathrm{mM} \mathrm{D}-2$ amino-5-phosphonopentanoic acid (AP-5), a competitive antagonist of the NMDA receptor (Tocris Cookson, Bristol, UK), $0.1 \mathrm{~mm}$ ketamine, a noncompetitive antagonist of the NMDA receptor (Sigma), or $0.5 \mathrm{~mm}$ 2,3-dihydroxy-6-nitro-7-sulfamoyl-benzo(F)quinoxaline (NBQX), a nonNMDA receptor antagonist (Tocris Cookson), with $0.5 \mathrm{~mm}$ NMDA into the pontine nucleus at P14-P16 (for each group, $n=6$ ). Then, by use of the same procedure described above, the extent of the lesion was measured to examine whether it is reduced by the antagonists.

Preparation for whole-cell recording. Rats from $\mathrm{P} 1$ to $\mathrm{P} 30$ were decapitated under ether anesthesia. After the brainstem including the pontine nucleus was isolated, frontal slices $(150 \mu \mathrm{m})$ were cut using a vibrating slicer (DSK 1000; Dosaka, Kyoto, Japan). Slices were incubated at $36^{\circ} \mathrm{C}$ for $1 \mathrm{hr}$ and then maintained at room temperature $\left(23-25^{\circ} \mathrm{C}\right)$ in a standard Ringer's solution containing (in $\mathrm{mM}$ ): $\mathrm{NaCl}, 124 ; \mathrm{KCl}, 2$; $\mathrm{KH}_{2} \mathrm{PO}_{4}, 1.5 ; \mathrm{NaHCO}_{3}, 26 ; \mathrm{MgCl}_{2}, 1 ; \mathrm{CaCl}_{2}, 2$; and glucose, 10 , $\mathrm{pH} 7.4$, when equilibrated with $95 \% \mathrm{O}_{2} / 5 \% \mathrm{CO}_{2}$. For experiments, slices were transferred into a superfusing chamber (volume, $\sim 0.5 \mathrm{ml}$ ) on a stage of an upright microscope equipped with an epifluorescence system (Axioskop; Zeiss), held down with a nylon net stretched out on a U-shaped piece of flattened platinum wire (Edwards et al., 1989), and perfused with a standard Ringer's solution equilibrated with $95 \% \quad \mathrm{O}_{2} / 5 \% \quad \mathrm{CO}_{2}$. Cells in the pontine nucleus were viewed under Nomarski optics with a water-immersion $40 \times$ objective (Zeiss) at a magnification of $640 \times$ and also monitored using a CCD camera and television monitor system (XC-77; Sony, Tokyo, Japan) at a magnification of $1000 \times$.

Solutions. Solutions were equilibrated with $95 \% \mathrm{O}_{2} / 5 \% \quad \mathrm{CO}_{2}$. Tetrodotoxin $(1 \mu \mathrm{M})$ (Wako, Osaka, Japan) and bicuculline $(20 \mu \mathrm{M})$ (Sigma) were added routinely to a standard Ringer's solution to block $\mathrm{Na}^{+}$ currents and spontaneous synaptic activities mainly mediated by GABA, respectively; glycine $(10 \mu \mathrm{M})$ (Wako) was also added to the solution to ensure a constant, saturating concentration of glycine for the NMDA receptor (Johnson and Ascher, 1987) (1 mM Mg ${ }^{2+}$ Ringer's solution). To release NMDA responses from a $\mathrm{Mg}^{2+}$ block (Mayer et al., 1984; Nowak et al., 1984), we reduced $\mathrm{Mg}^{2+}$ to $0.1 \mathrm{~mm}\left(0.1 \mathrm{~mm} \mathrm{Mg}{ }^{2+}\right.$ Ringer's solution) or omitted $\mathrm{Mg}^{2+}$ from the solution (we defined this solution as a nominally $0 \mathrm{~mm} \mathrm{Mg}^{2+}$ Ringer's solution in the present study). To examine the permeation of $\mathrm{Ca}^{2+}$ through NMDA receptor channels in the presence of $\mathrm{Mg}^{2+}$, we changed the solution to a $\mathrm{Ca}^{2+}$ Ringer's solution in which $\mathrm{Na}^{+}$and $\mathrm{K}^{+}$were replaced with an impermeant cation $N$-methylglucamine (NMG) (Sigma) (Iino et al., 1990). The $\mathrm{Ca}^{2+}$ Ringer's solution contained $135 \mathrm{~mm}$ NMG, $10 \mathrm{~mm}$ glucose, $10 \mathrm{~mm}$ HEPES, 10 $\mathrm{mM} \mathrm{CaCl}_{2}, 5 \mathrm{~mm} \mathrm{MgCl}_{2}, 1 \mu \mathrm{M}$ tetrodotoxin, $20 \mu \mathrm{M}$ bicuculline, and 10 $\mu \mathrm{M}$ glycine, equilibrated with $\mathrm{O}_{2}$ and adjusted to $\mathrm{pH} 7.4$ with $\mathrm{HCl}$; the osmolarity was $\sim 305 \mathrm{mOsm} / \mathrm{l}$.

Patch pipettes were pulled from thin-walled glass (GC150TF-15; Clark Electromedical Instruments, Pangbourne, UK), coated with Sylgard resin, and fire-polished to a final resistance of 8-10 $\mathrm{M} \Omega$. The pipette solution contained (in $\mathrm{mM}$ ): $\mathrm{Cs}$ gluconate, 110; $\mathrm{CsCl}, 40 ; \mathrm{NaCl}, 4$; HEPES, 10; EGTA, 5; $\mathrm{CaCl}_{2}, 0.5$; and Mg-ATP, 2, adjusted to $\mathrm{pH} 7.2$ with $\mathrm{CsOH}$; the osmolarity was $\sim 295 \mathrm{mOsm} / 1$.

Drug application. NMDA was applied by bath application to examine current responses evoked by a long-lasting high concentration of extracellular glutamate that is considered to be induced under hypoxic conditions (Benveniste et al., 1984; Hagberg et al., 1985; Globus et al., 1991; Mitani et al., 1992, 1994b) or was applied by ionophoresis to examine developmental changes in the voltage-dependent $\mathrm{Mg}^{2+}$ block of NMDA receptor channels at various membrane potentials and also was applied by ionophoresis to examine the permeation of $\mathrm{Ca}^{2+}$ through NMDA receptor channels. For bath application, $50 \mu \mathrm{M}$ NMDA was dissolved in a $1 \mathrm{mM} \mathrm{Mg}^{2+}$ or a nominally $0 \mathrm{mM} \mathrm{Mg}^{2+}$ Ringer's solution. The $50 \mu \mathrm{M}$ NMDA solution was applied to a slice for 2 min by switching the superfusion line at the inlet of the recording chamber with magnetic pinch valves. The dead-space time was $\sim 5 \mathrm{sec}$. Usually, a single trial of the NMDA bath application was performed in each slice. For ionophoric application, a high-resistance $(100 \mathrm{M} \Omega)$ electrode was used. The electrode was filled with $100 \mathrm{~mm}$ NMDA solution. To dissolve NMDA, we added NMG to the solution until the $\mathrm{pH}$ was raised to 7.4 (Iino et al., 1990). The NMDA was applied to the soma perfused with a nominally 0 , 0.1 , or $1 \mathrm{~mm} \mathrm{Mg}^{2+}$ Ringer's solution using $100 \mathrm{msec}$ current pulses of $100-500 \mathrm{nA}$ intensity at a frequency of $0.05 \mathrm{~Hz}$; a retaining current of $1-5$ $\mathrm{nA}$ was used to prevent leakage. All recordings are performed at room temperature $\left(23-25^{\circ} \mathrm{C}\right)$.

Whole-cell recording. Whole-cell recordings were made from $\mathrm{PN}$ neurons using an EPC-9 (List, Germany) amplifier. The seal resistance was usually $>10 \mathrm{G} \Omega$. Holding potentials were corrected for the liquid junction potential between pipette solution and superfusate (approximately $+7 \mathrm{mV}$ ). The cell capacitance was measured from transient currents produced by $10 \mathrm{mV}$ hyperpolarizing-voltage steps. NMDA-induced currents were low-pass filtered at $10 \mathrm{kHz}$ (three-pole Bessel filter) and stored on a pulse code modulation data recorder for later off-line analysis. In addition, by the use of a CCD camera and television monitor system at a magnification of $1000 \times$, the cell body size of recorded neurons was evaluated by measuring major and minor diameters; the major diameter was the longest axis, and the longest diameter at a right angle to the longest axis was defined as the minor diameter.

In some experiments, whole-cell recordings were made from retrogradely labeled PN neurons after injection of a fluorescent dye into the cerebellar cortex. The micropipettes (tip diameter, 50-60 $\mu \mathrm{m}$ ) were filled with $10 \%$ rhodamine-B dextran-amine (70,000 MW; Molecular Probes, Eugene, OR) dissolved in $0.9 \%$ saline (Schmued et al., 1990), and pressure injections (total volume, $1 \mu \mathrm{l}$; $0.04 \mu \mathrm{l} / \mathrm{min}$ for $25 \mathrm{~min}$ ) were accomplished into the cerebellar cortex of rats at P8-P25 with the same procedure that was used for in vivo injection of NMDA. After 4-6 d of survival, brainstem slices that included the pontine nucleus were made from the rats. After identification of retrogradely labeled pontinecerebellar-projecting PN neurons, whole-cell recordings were made from the labeled PN neurons (Manabe et al., 1991).

In situ hybridization. Rats at P1, P7, P11, P14, P21, and 4 months of age (adult) were deeply anesthetized with pentobarbital and then killed by decapitation. The brains were fresh frozen in powdered dry ice. Subsequently, frontal sections were cut at $20 \mu \mathrm{m}$ on a cryostat and mounted on glass slides. They were fixed with $4 \%$ paraformaldehyde in $0.1 \mathrm{M}$ phosphate buffer for $10 \mathrm{~min}$ and then acetylated with $0.25 \%$ acetic anhydride 

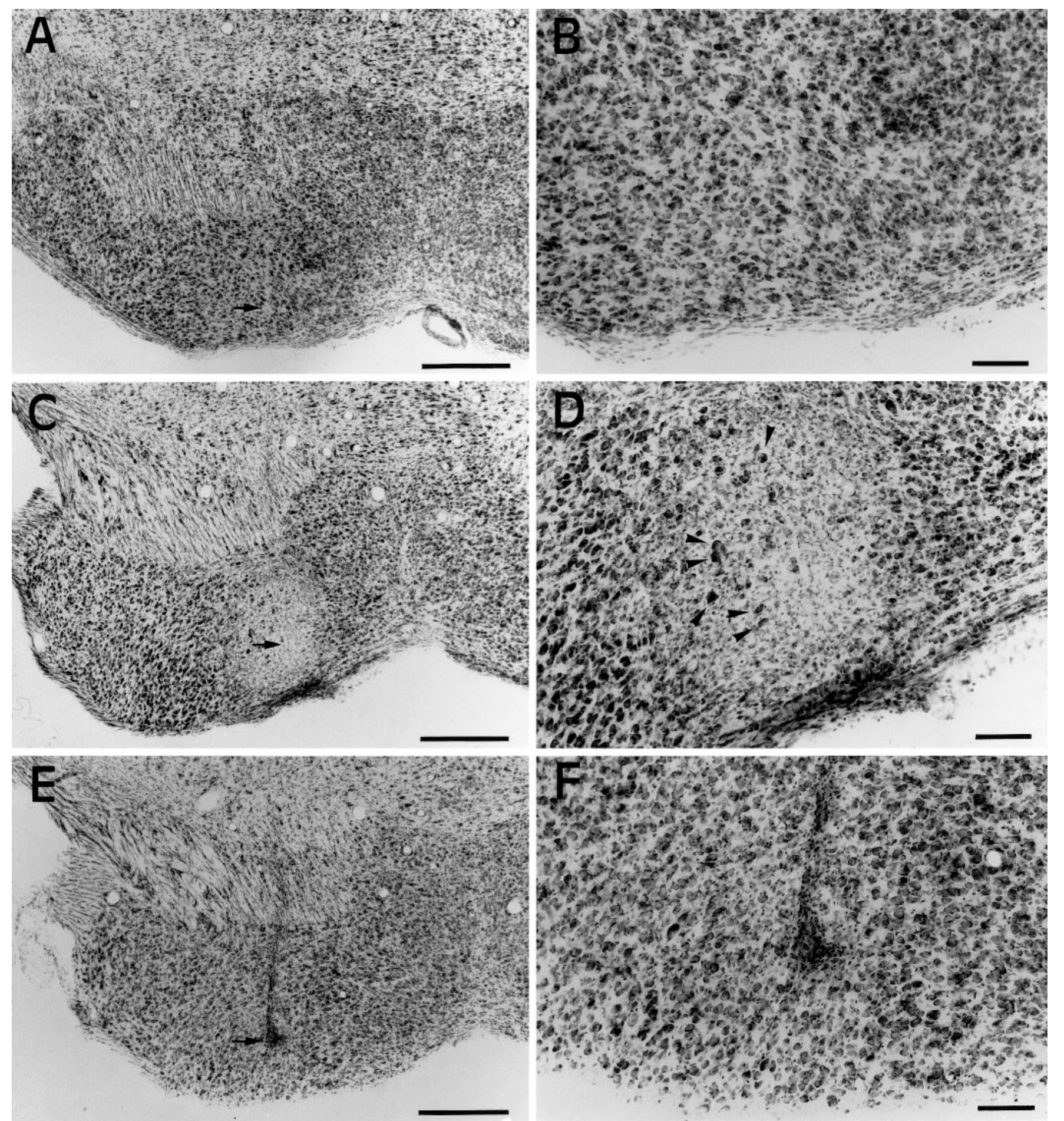

Figure 1. Changes in the susceptibility of neurons in the pontine nucleus to NMDA neurotoxicity during postnatal development. Nissl-stained frontal brainstem sections are shown. A unilateral injection of $0.5 \mathrm{~mm}$ NMDA (total volume, $1 \mu \mathrm{l} ; 0.04 \mu \mathrm{l} / \mathrm{min}$ for 25 min) was made into the developing rat pontine nucleus, and the animals were killed $4 \mathrm{~d}$ later. $A, C, E$, The severity of the brain lesion is maximal at P14; substantial neuronal loss is observed in the pontine nucleus $(C)$. In comparison with that at P14, obvious neuronal loss is not observed at $\mathrm{P} 7(A)$ and $\mathrm{P} 28(E)$ except for occasional appearances of reactive glial cells surrounding the track of a micropipette and the injection site $(E)$. Arrows indicate traces of the tip of a micropipette for injection. $B, D, F$, Higher magnifications of the pontine nucleus surrounding the NMDA injection site in $A, C$, and $E$, respectively, are shown. Note that some normal-appearing neurons are observed in the lesion (some of them are indicated by arrowheads in $D$ ). Scale bars: $A, C, E, 0.4 \mathrm{~mm} ; B, D, F$, $0.1 \mathrm{~mm}$.

in $0.1 \mathrm{~m}$ triethanolamine- $\mathrm{HCl}, \mathrm{pH} 8.0$, for $10 \mathrm{~min}$. For isotopic detection of mRNAs for the rat NMDA receptor subunits that have been designated as NR1, NR2A, NR2B, NR2C, and NR2D, 45-mer nonoverlapping antisense oligonucleotides were synthesized against nucleotide res- idues 236-280 of the rat NR1 cDNA (Hollmann et al., 1993; accession number L08228), residues 3189-3233 of the rat NR2A cDNA (Money et al., 1992; accession number M91561), residues 3242-4286 of the rat NR2B cDNA (Money et al., 1992; accession number M91562), residues 


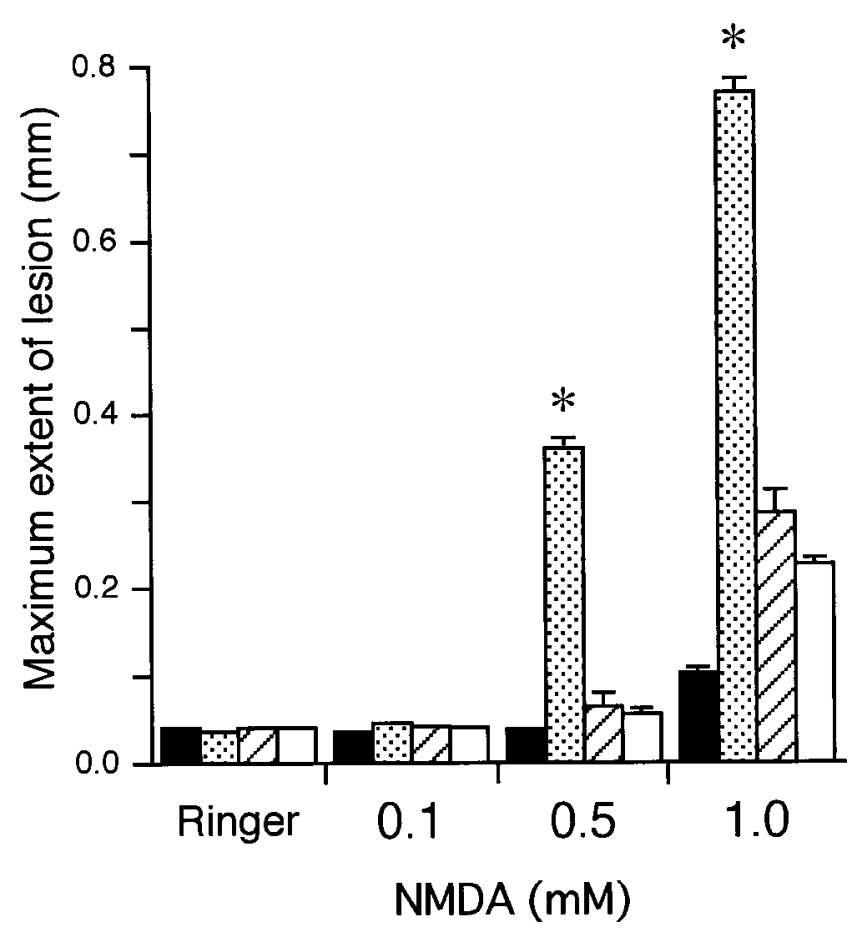

Figure 2. Dose-response comparison of the maximum extent of NMDA-induced lesion during postnatal development. Animals received a unilateral injection of Ringer's solution or of $0.1,0.5$, or 1.0 mM NMDA (total volume, $1 \mu \mathrm{l} ; 0.04 \mu \mathrm{l} / \mathrm{min}$ for $25 \mathrm{~min}$ ) into the pontine nucleus and were killed $4 \mathrm{~d}$ later. The serial sections of the pontine nucleus were scanned to determine which section contained the largest lesion, and the longest axis of the lesion was evaluated as the maximum extent of lesion. Data represent mean \pm SEM (bars) (each column for NMDA, $n=6$; each column for Ringer's solution, $n=2$ ). After injections of 0.5 or $1.0 \mathrm{~mm}$ NMDA, the extent of lesion at P14-P16 (stippled columns) is significantly larger than the corresponding value at P5-P7 ( filled columns), P20-P21 (hatched columns), and P28-P30 (open columns). Statistical analysis consisted of one-way ANOVA and Bonferroni/Dunn post hoc tests $\left({ }^{*} p<\right.$ 0.0001, compared with values at P5-P7, P20-P21, and P28-P30).

144-188 of the rat NR2C cDNA (Money et al., 1992; accession number M91563), and residues 2951-2995 of the rat NR2D (Money et al., 1994; accession number L31611). Oligonucleotides were labeled with ${ }^{35} \mathrm{~S}$ dATP to a specific activity of $0.5 \times 10^{9} \mathrm{dpm} / \mu \mathrm{g}$ of DNA by the use of terminal deoxyribonucleotidyl transferase (BRL, Bethesda, MD). After prehybridization at room temperature for $1 \mathrm{hr}$ in a hybridization buffer containing $50 \%$ formamide, $50 \mathrm{~mm}$ Tris- $\mathrm{HCl}, \mathrm{pH} 7.5,0.02 \%$ Ficoll, $0.02 \%$ polyvinylpyrrolidone, $0.02 \%$ bovine serum albumin, $0.6 \mathrm{M} \mathrm{NaCl}$, $0.25 \%$ sodium dodecyl sulfate, $200 \mu \mathrm{g} / \mathrm{ml}$ tRNA, $1 \mathrm{~mm}$ EDTA, and $10 \%$ dextran sulfate, the hybridization was performed at $42^{\circ} \mathrm{C}$ for $10 \mathrm{hr}$ in the hybridization buffer supplemented with $10,000 \mathrm{cpm} / \mu$ l of ${ }^{35} \mathrm{~S}$-labeled oligonucleotide probes and $0.1 \mathrm{~m}$ dithiothreitol. Then, the slides were washed twice at $55^{\circ} \mathrm{C}$ for $40 \mathrm{~min}$ in $0.1 \times \mathrm{SSC}(1 \times \mathrm{SSC}, 0.15 \mathrm{M} \mathrm{NaCl}$ and $0.015 \mathrm{M}$ sodium citrate) containing $0.1 \%$ sarcosyl and were exposed for 3 weeks to Hyperfilm $\beta$-max (Amersham, Arlington Heights, IL). Other details pertaining to the histological procedures for in situ hybridization are described elsewhere (Watanabe et al., 1992, 1993).

Data analysis. Data obtained by whole-cell recordings were analyzed using the data analysis software EP Analysis (version 1.1) (Shoshin, Okazaki, Japan) on a Macintosh computer. All values in the text are expressed as mean \pm SEM. Statistical significance was assessed using ANOVA with a Bonferroni/Dunn post hoc analysis for intergroup significance of difference.

\section{RESULTS}

\section{Susceptibility to NMDA neurotoxicity}

The extent of the lesion produced by direct injection of NMDA into the pontine nucleus varied over postnatal development (Figs.

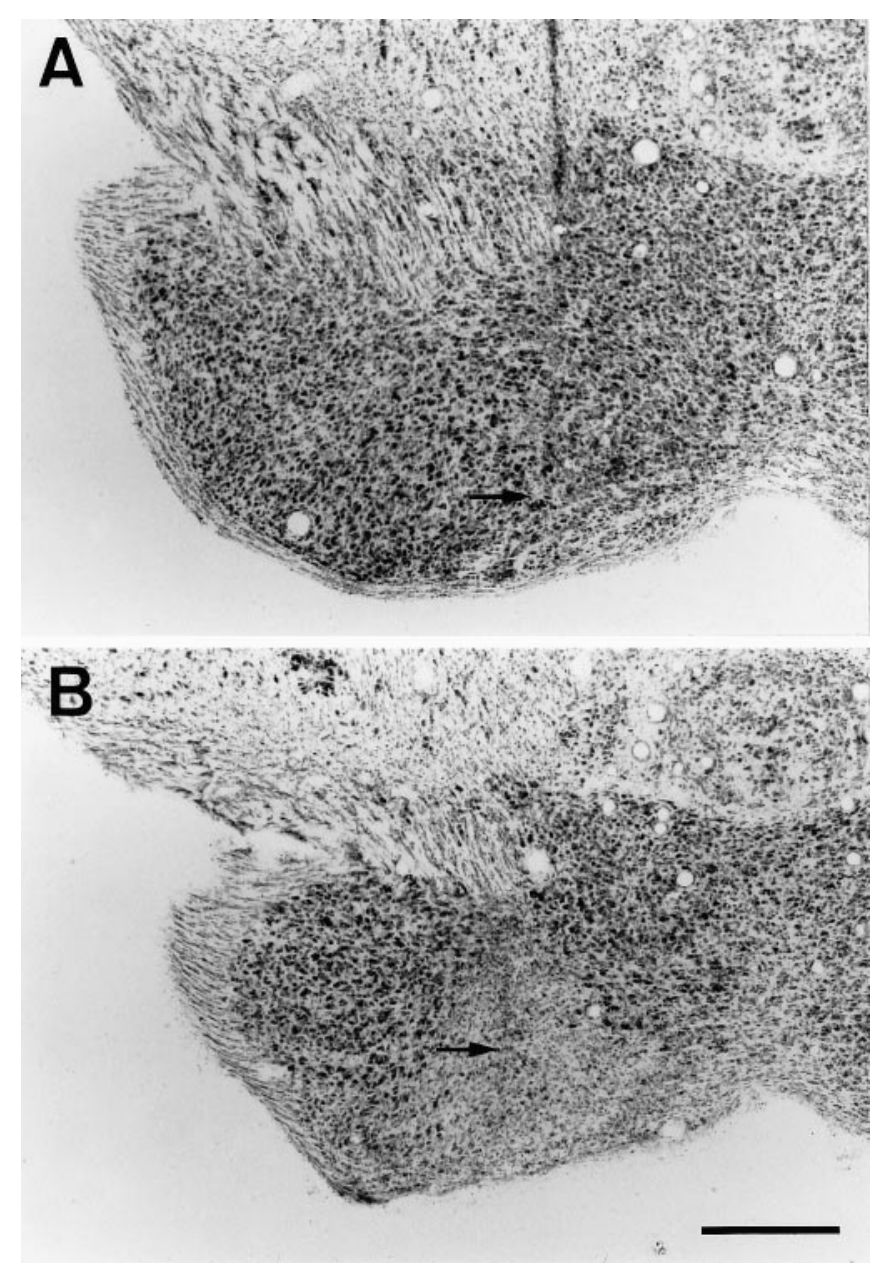

Figure 3. Effects of NMDA and non-NMDA receptor antagonists on NMDA neurotoxicity during postnatal development. Nissl-stained frontal brainstem sections are shown. $A$, Ketamine $(0.1 \mathrm{~mm})$, a noncompetitive antagonist of the NMDA receptor, was injected with $0.5 \mathrm{~mm}$ NMDA (total volume, $1 \mu \mathrm{l} ; 0.04 \mu \mathrm{l} / \mathrm{min}$ for $25 \mathrm{~min}$ ) into the pontine nucleus at P14. $B, \mathrm{NBQX}(0.5 \mathrm{~mm})$, a non-NMDA receptor antagonist, was injected with $0.5 \mathrm{~mm}$ NMDA into the pontine nucleus at P14. The animals were killed $4 \mathrm{~d}$ later. The lesion produced by $0.5 \mathrm{~mm}$ NMDA is blocked by 0.1 mM ketamine $(A)$ but not by $0.5 \mathrm{~mm} \operatorname{NBQX}(B)$; obvious neuronal loss is observed surrounding the injection site in $B$. Arrows indicate traces of the tip of a micropipette. Scale bar, $0.4 \mathrm{~mm}$.

1,2). Injection of $0.1 \mathrm{~mm}$ NMDA produced a very small lesion in the pontine nucleus at any age; the lesion was confined to the tract of micropipettes, and the size did not differ from that of the injection of a Ringer's solution (Fig. 2). Injection of $0.5 \mathrm{~mm}$ NMDA produced substantial neuronal loss in the pontine nucleus at P14-P16; extensive lesion with a diameter of $\sim 0.4 \mathrm{~mm}$ was produced (Fig. $1 C, D$ ). In contrast, the $0.5 \mathrm{~mm}$ NMDA injection did not show any obvious neuronal loss in the pontine nucleus at P5-P7, P20-P21, and P28-P30 (Figs. 1A,B,E,F, 2) except for occasional appearances of reactive glial cells surrounding the tract of micropippetes and the injection site at P20-P21 (data not shown) and P28-P30 (Fig. 1E,F). Injection of $1.0 \mathrm{~mm}$ NMDA produced more widespread neuronal loss in the pontine nucleus at P14-P16 and produced restricted neuronal loss or disruption of the normal cytoarchitecture in the pontine nucleus at P5-P7, P20-P21, and P28-P30 (Fig. 2). Quantitative analysis of the extent of lesion demonstrated that the pontine nucleus at P14P16 was most susceptible to the toxicity of NMDA; post hoc 
$0 \mathrm{mM} \mathrm{Mg}^{2+}$

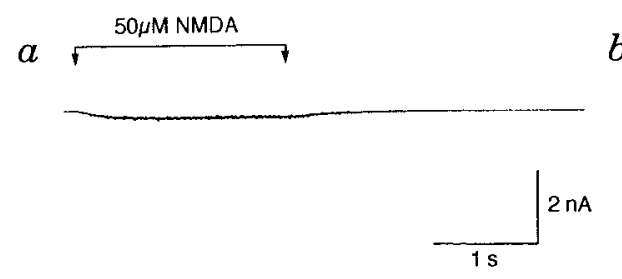

$b \longdiv { 7 }$

c
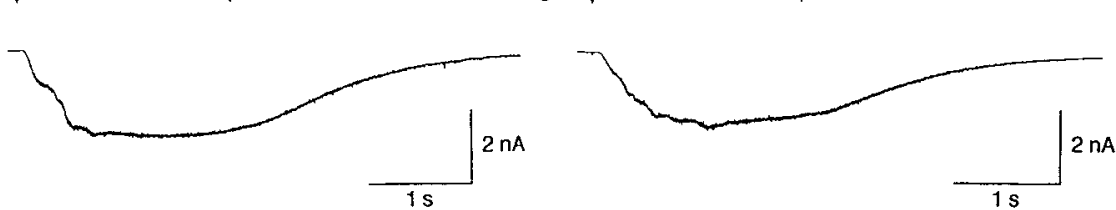

$1 \mathrm{mM} \mathrm{Mg}^{2+}$
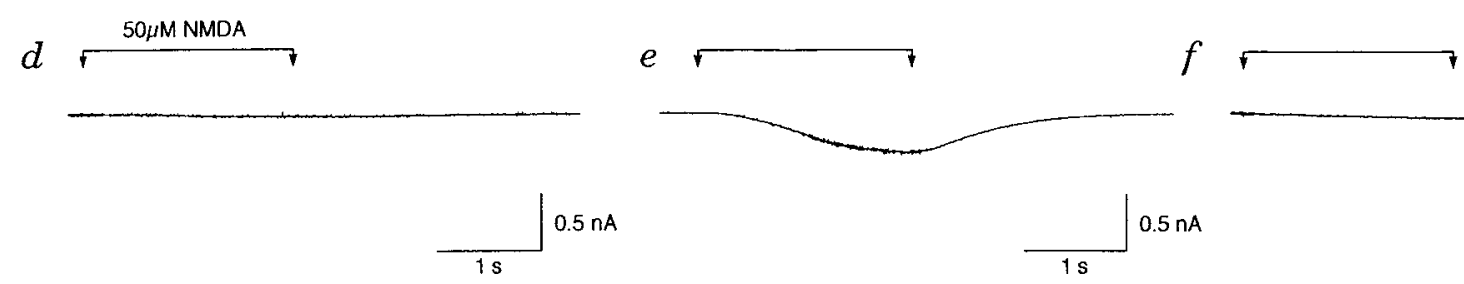

$1 \mathrm{~s}$
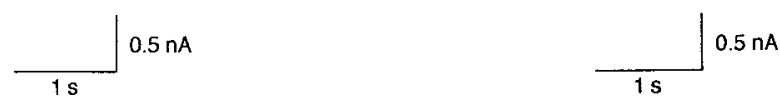

Figure 4. Whole-cell responses to bath application of NMDA $(50 \mu \mathrm{M})$ during postnatal development. The responses were recorded at $-80 \mathrm{mV}$ in the presence of $0 \mathrm{mM} \mathrm{Mg}^{2+}(a-c)$ and $1.0 \mathrm{mM} \mathrm{Mg}^{2+}(d-f)$ from neurons in the pontine nucleus at $\mathrm{P} 2(a, d), \mathrm{P} 15(b, e)$, and $\mathrm{P} 29(c, f)$. The paired arrows indicate the duration of NMDA application. Small responses to NMDA are observed in neurons of the pontine nucleus at $\mathrm{P} 2$ in a nominally $0 \mathrm{mM} \mathrm{Mg}^{2+}$ Ringer's solution $(a)$ and in a $1 \mathrm{mM} \mathrm{Mg}{ }^{2+}$ Ringer's solution $(d)$. Large responses to NMDA are observed in neurons of the pontine nucleus at P15 (b) and P29 (c) in a nominally $0 \mathrm{mM} \mathrm{Mg}^{2+}$ Ringer's solution. In the presence of $1.0 \mathrm{mM} \mathrm{Mg}^{2+}$, the response to NMDA at P29 shows a typical Mg${ }^{2+}$ block; the NMDA-induced current is markedly reduced $(f)$. In contrast, the degree of $\mathrm{Mg}^{2+}$ block at P14 is smaller than that at P29; a substantial NMDA-induced current is induced even in the presence of $1.0 \mathrm{mM} \mathrm{Mg}{ }^{2+}(e)$. Solutions contained $1 \mu \mathrm{M}$ tetrodotoxin, $20 \mu \mathrm{M}$ bicuculline, and $10 \mu \mathrm{M}$ glycine.

analysis showed that the extent of lesion at P14-P16 was significantly larger than that at P5-P7, P20-P21, and P28-P29 ( $p<$ 0.0001, after injections of 0.5 and $1.0 \mathrm{~mm}$ NMDA) (Fig. 2). Interestingly, some normal-appearing neurons were observed in the lesion sites produced by NMDA (Fig. 1D). This means that some neurons that are comparatively tolerant to the toxicity of NMDA intermingle with many neurons that are susceptible to the toxicity of NMDA in the developing pontine nucleus. They may be interneurons in the pontine nucleus.

To confirm that the NMDA neurotoxicity elicited is attributable to NMDA receptor stimulation, we examined in the pontine nucleus at P14-P16 whether the lesion produced by the NMDA injection is reduced by NMDA receptor antagonists AP-5 and ketamine but not by the non-NMDA receptor antagonist NBQX. The lesion produced by $0.5 \mathrm{mM}$ NMDA was markedly reduced by $1 \mathrm{~mm}$ AP-5 [maximum extent of lesion, $41.8 \pm 7.9 \mu \mathrm{m}(n=6$; mean $\pm \mathrm{SEM})]($ data not shown) and $0.1 \mathrm{~mm}$ ketamine [maximum extent of lesion, $37.5 \pm 5.6 \mu \mathrm{m}(n=6)]$ (Fig. $3 A)$ but not by $0.5 \mathrm{~mm}$ NBQX [maximum extent of lesion, $417.5 \pm 47.4 \mu \mathrm{m}(n=$ 6)] (Fig. 3B).

These results indicate that the susceptibility of neurons in the pontine nucleus to NMDA neurotoxicity markedly changes during postnatal development and that the susceptibility peaks near postnatal day 15 in the developing pontine nucleus.

\section{Developing changes in cell body size and capacitance}

The cell body size of recorded neurons, which was measured using a CCD camera and television monitor system at a magnification of $1000 \times$, increased during the first two postnatal weeks; the major and minor diameters of neurons were $12.1 \pm 0.7$ and
$9.3 \pm 0.4 \mu \mathrm{m}$ at $\mathrm{P} 1-\mathrm{P} 2(n=14)$ and $22.3 \pm 0.8$ and $16.1 \pm 0.6 \mu \mathrm{m}$ at P15-P16 ( $n=16$; mean \pm SEM). After postnatal day 16 , there were no significant changes in cell body size; the major and minor diameters of neurons were $21.1 \pm 0.8$ and $15.4 \pm 0.6 \mu \mathrm{m}$ at P29-P30 $(n=14)$. In addition, the capacitance of PN neurons increased during the first two postnatal weeks from $3.2 \pm 0.3 \mathrm{pF}$ at $\mathrm{P} 1-\mathrm{P} 2(n=14)$ to $13.2 \pm 0.6 \mathrm{pF}$ at $\mathrm{P} 15-\mathrm{P} 16(n=37)$. After postnatal day 16 , no significant changes in the capacitance with age were observed; the capacitance at P29-P30 was $14.6 \pm 0.7 \mathrm{pF}$ $(n=24)$. These results indicate that the cell membrane surface of PN neurons shows a fourfold increase and reaches the adult value during the first two postnatal weeks.

\section{Current responses evoked by a long-lasting high concentration of extracellular NMDA}

Bath application of NMDA $(50 \mu \mathrm{M})$ induced small currents in the PN neurons at P1-P2 in a nominally $0 \mathrm{mM} \mathrm{Mg}^{2+}$ and also in a 1 $\mathrm{mM} \mathrm{Mg}^{2+}$ Ringer's solution (Figs. $\left.4 a, d, 5\right)$. The NMDA-induced currents in a nominally $0 \mathrm{~mm} \mathrm{Mg}^{2+}$ Ringer's solution steeply increased during the first two postnatal weeks (Fig. 5A); large NMDA-induced currents were evoked in the PN neurons near postnatal day 15 (Fig. 4b). The currents of P15-P16 neurons held at $-80 \mathrm{mV}$ were $\sim 33$ times greater than those of P1-P2 neurons held at $-80 \mathrm{mV}$. The NMDA-induced currents in a $1 \mathrm{mM} \mathrm{Mg}^{2+}$ Ringer's solution also markedly increased during the first two postnatal weeks and reached a peak at P15-P16 (Fig. 5B). Substantial NMDA-induced currents were observed in the PN neurons near postnatal day 15 even in the presence of $1 \mathrm{mM} \mathrm{Mg} \mathrm{Mg}^{2+}$ (Fig. 4e). The currents of P15-P16 neurons held at $-80 \mathrm{mV}$ were $\sim 31$ times greater than those of P1-P2 neurons held at $-80 \mathrm{mV}$. 

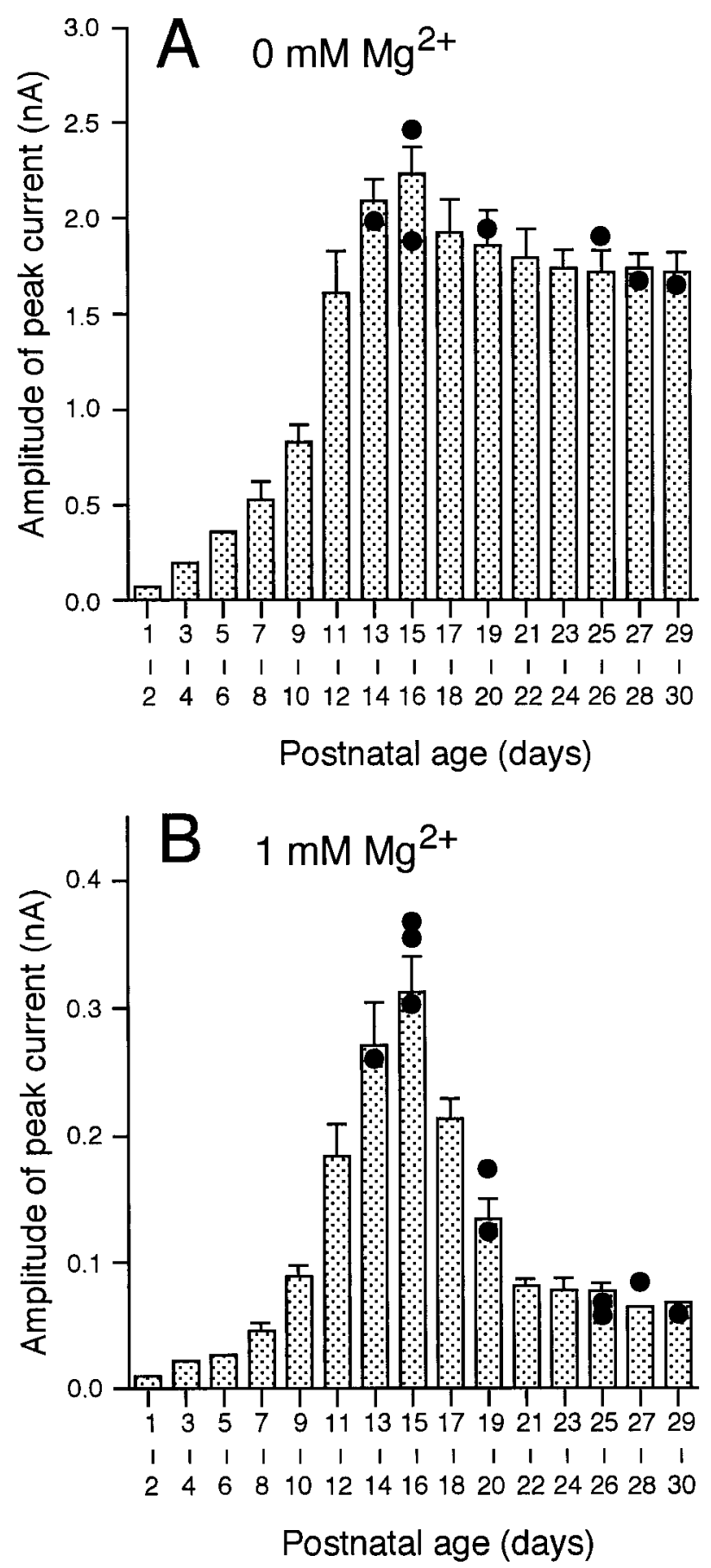

Figure 5. Developmental changes in whole-cell responses to bath application of NMDA $(50 \mu \mathrm{M})$ during postnatal development. Histograms show pooled data of peak amplitudes of NMDA-induced currents (error bars represent SEM; $n=6-20)$. The responses were recorded from developing neurons in the pontine nucleus at $-80 \mathrm{mV}$ in the presence of $0 \mathrm{mM} \mathrm{Mg}{ }^{2+}(A)$ and $1.0 \mathrm{~mm} \mathrm{Mg}^{2+}(B)$. In a nominally $0 \mathrm{~mm} \mathrm{Mg} \mathrm{Mg}^{2+}$ solution $(A)$, the responses at $\mathrm{P} 13-\mathrm{P} 14$ and $\mathrm{P} 15-\mathrm{P} 16$ are significantly greater than those at P1-P2, P3-P4, P5-P6, P7-P8, and P9-P10 (one-way ANOVA and Bonferroni/Dunn post hoc tests; $p<0.0001)$. In the presence of $1.0 \mathrm{~mm} \mathrm{Mg}{ }^{2+}$, the responses at P13-P14 and P15-P16 are significantly greater than those at P1-P2, P3-P4, P5-P6, P7-P8, P9-P10, P19-P20, P21-P22, P23-P24, P25-P26, P27-P28, and P29-P30 (one-way ANOVA and Bonferroni/Dunn post hoc tests; $p<0.0001)$. Solid circles indicate the peak current amplitudes recorded from retrogradely labeled neurons in the pontine nucleus after injection of a fluorescent dye into the cerebellar cortex (10\% rhodamine-B dextran-amine).
After postnatal day 16, the NMDA-induced currents in a nominally $0 \mathrm{~mm} \mathrm{Mg}^{2+}$ Ringer's solution slightly decreased, and the amplitudes of the currents were maintained at comparatively high levels (Fig. 5A); large NMDA-induced currents were evoked in the PN neurons at P29-P30 held at $-80 \mathrm{mV}$ in a nominally $0 \mathrm{~mm}$ $\mathrm{Mg}^{2+}$ Ringer's solution (Fig. 4c). In contrast, the NMDAinduced currents in a $1 \mathrm{mM} \mathrm{Mg}^{2+}$ Ringer's solution markedly declined (Fig. 5B). When the PN neurons at P29-P30 were perfused with a $1 \mathrm{mM} \mathrm{Mg}^{2+}$ Ringer's solution, the amplitudes of the NMDA-induced currents were markedly reduced (Fig. $4 f$ ). This $\mathrm{Mg}^{2+}$ block of NMDA-induced currents is a typical feature of NMDA receptors, and this observation is consistent with that in previous studies (Mayer et al., 1984; Nowak et al., 1984). Generally, NMDA receptor channels are sensitive to voltagedependent block by $\mathrm{Mg}^{2+}$, and the activation of NMDA receptor channels is usually blocked by $\mathrm{Mg}^{2+}$ at resting membrane potentials. Therefore, the present NMDA responses that are activated at $-80 \mathrm{mV}$ in a $1 \mathrm{~mm} \mathrm{Mg}^{2+}$ Ringer's solution in the PN neurons near postnatal day 15 are considered to be relatively insensitive to $\mathrm{Mg}^{2+}$.

Whole-cell recordings from retrogradely labeled PN neurons revealed that labeled PN neurons, which were identified as pontine-cerebellar-projecting PN neurons, showed the same developmental changes in NMDA-induced currents that are described above (Fig. 5, solid circles). This result means that the developmental changes in the NMDA-induced currents observed in the present study represent those of the pontine-cerebellarprojecting $\mathrm{PN}$ neurons.

These results indicate that NMDA-induced currents that are relatively insensitive to $\mathrm{Mg}^{2+}$ increase and reach a peak in developing PN neurons near postnatal day 15 when PN neurons are most susceptible to NMDA toxicity.

\section{Voltage-dependent $\mathbf{M g}^{2+}$ block}

Whole-cell recordings were made from PN neurons at P3-P4 ( $n=$ 12), $\mathrm{P} 14-\mathrm{P} 15(n=12)$, and $\mathrm{P} 28-\mathrm{P} 29(n=12)$. Ionophoretic applications of NMDA were performed to evoke current responses in PN neurons perfused with a nominally $0,0.1$, or $1 \mathrm{~mm}$ $\mathrm{Mg}^{2+}$ Ringer's solution. Current-voltage relationships were obtained for the current responses to NMDA at P3-P4, P14-P15, and P28-P29. The currents reversed close to $0 \mathrm{mV}$ in all cases. At P3-P4 and P28-P29, the current responses to NMDA in a nominally $0 \mathrm{~mm} \mathrm{Mg}^{2+}$ Ringer's solution varied nearly linearly with a wide range of membrane potentials (Fig. 6Aa,Ac,Ba,Bc, open circles). In the presence of extracellular $\mathrm{Mg}^{2+}$, the current responses showed a typical voltage-dependent block by $\mathrm{Mg}^{2+}$. The addition of extracellular $0.1 \mathrm{~mm} \mathrm{Mg}^{2+}$ produced little change in the outward currents but markedly reduced the inward currents (Fig. 6Ad,Af,Ba,Bc, solid circles). The blocking effect of $\mathrm{Mg}^{2+}$ increased as the membrane potential was hyperpolarized. The voltage-dependent $\mathrm{Mg}^{2+}$ block of the current responses to NMDA was more pronounced in $1 \mathrm{~mm} \mathrm{Mg}^{2+}$ (Fig. 6Ba, Bc, solid triangles). At P14-P15, the current responses to NMDA in a nominally $0 \mathrm{~mm} \mathrm{Mg}^{2+}$ Ringer's solution varied nearly linearly with a wide range of membrane potentials (Fig. $6 \mathrm{Ab}, \mathrm{Bb}$, open circles). In the presence of extracellular $\mathrm{Mg}^{2+}$, the current responses to NMDA at P14-P15 showed resistance to the voltagedependent block by $\mathrm{Mg}^{2+}$. The addition of extracellular $0.1 \mathrm{~mm}$ $\mathrm{Mg}^{2+}$ produced little change in the outward currents and induced limited reductions in inward currents. The degree of voltagedependent block by $0.1 \mathrm{~mm} \mathrm{Mg}{ }^{2+}$ was smaller compared with that at P3-P4 and at P28-P29 (Fig. 6Ae,Bb, solid circles). The decrease 


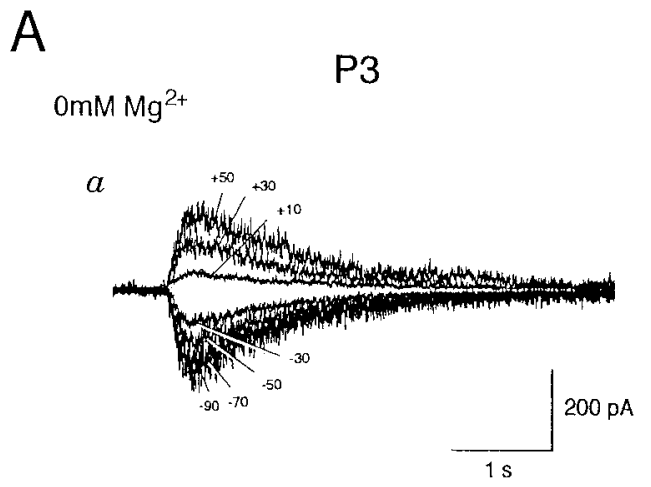

P14

P28

$0.1 \mathrm{mM} \mathrm{Mg}^{2+}$

$d$

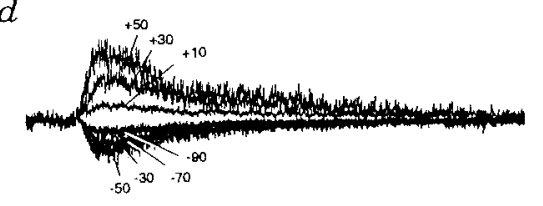

B

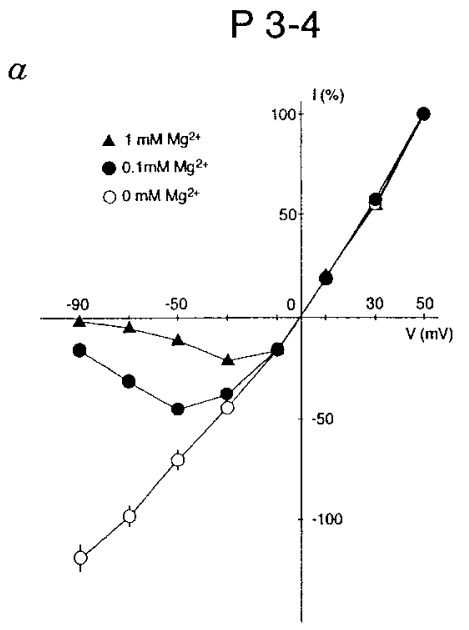

$b$

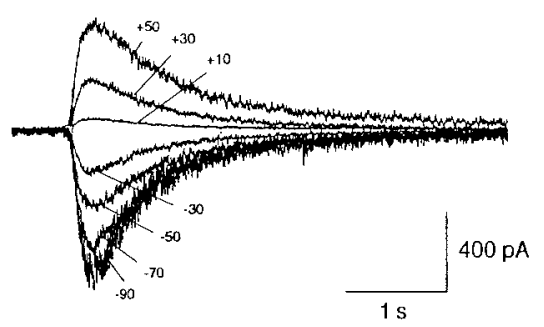

$e$

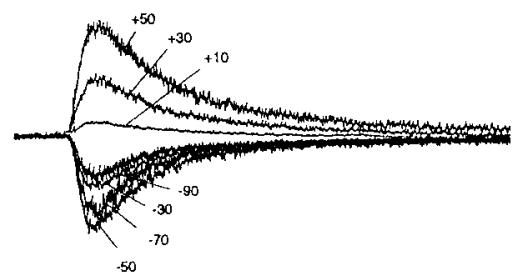

P 14-15

$b$

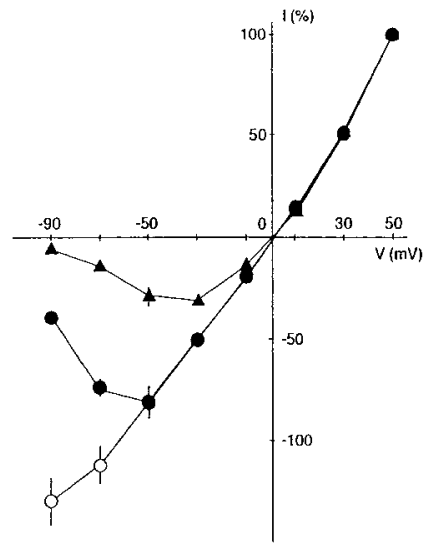

$c$

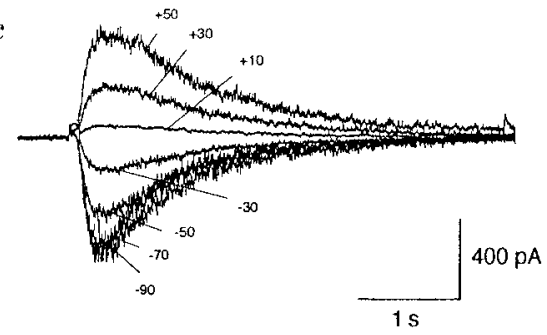

f

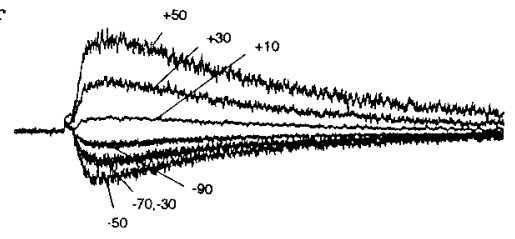

P 28-29

$c$

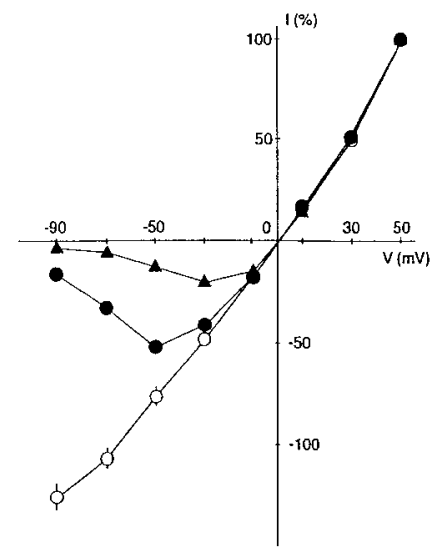

Figure 6. Voltage-dependent $\mathrm{Mg}^{2+}$ block of current responses to NMDA during postnatal development. $A$, Current responses recorded in a nominally $0 \mathrm{mM} \mathrm{Mg}{ }^{2+}$ Ringer's solution $(a-c)$ and in a $0.1 \mathrm{mM} \mathrm{Mg}{ }^{2+}$ Ringer's solution $(d-f)$ at different holding potentials are superimposed; holding potentials (in $\mathrm{mV}$ ) are indicated in $a-f$. Ionophoretic applications of NMDA were performed to evoke current responses of neurons in the pontine nucleus at 3 $(a, d), \mathrm{P} 14(b, e)$, and P28 $(c, f) . B$, Current-voltage relationships of the responses to NMDA obtained from neurons in the pontine nucleus at P3-P4 $(a), \mathrm{P} 14-\mathrm{P} 15(b)$, and $\mathrm{P} 28-\mathrm{P} 29(c)$ are shown. Data points are obtained in a nominally $0 \mathrm{~mm} \mathrm{Mg}{ }^{2+}$ Ringer's solution (open circles) and in the presence of $0.1 \mathrm{~mm} \mathrm{Mg}^{2+}$ (solid circles) and $1 \mathrm{mM} \mathrm{Mg}^{2+}$ (solid triangles). All solutions contained $1 \mu \mathrm{M}$ tetrodotoxin, $20 \mu \mathrm{M}$ bicuculline, and $10 \mu \mathrm{M}$ glycine. The peak amplitudes of the responses to NMDA were normalized to the mean value at $+50 \mathrm{mV}$ in each experimental condition. Data are mean \pm SEM $(n=12)$.

in the blocking effect of $\mathrm{Mg}^{2+}$ was also observed after the addition of extracellular $1 \mathrm{~mm} \mathrm{Mg}^{2+}$ (Fig. $6 \mathrm{Bb}$, solid triangles). At a holding potential of $-70 \mathrm{mV}$, the remaining proportion of the peak amplitude of current responses in $0.1 \mathrm{mM} \mathrm{Mg}^{2+}$ was $66.1 \pm$ $5.6 \%$ of that in a nominally $0 \mathrm{~mm} \mathrm{Mg}^{2+}$ Ringer's solution at $\mathrm{P} 14-\mathrm{P} 15$, whereas it was $33.2 \pm 2.5 \%$ of that at P3-P4 and $31.4 \pm$ $2.5 \%$ of that at P28-P29 $(p<0.0001$, Bonferroni/Dunn post hoc tests) (Fig. $7 A$ ). Also the proportion of the current responses remaining unblocked in $1 \mathrm{~mm} \mathrm{Mg}^{2+}$ was $12.4 \pm 1.3 \%$ of that in a nominally $0 \mathrm{mM} \mathrm{Mg}^{2+}$ Ringer's solution at P14-P15, whereas it was $5.5 \pm 0.2 \%$ of that at $\mathrm{P} 3-\mathrm{P} 4$ and $5.8 \pm 0.7 \%$ of that at P28-P29 ( $p<0.0001$, Bonferroni/Dunn post hoc tests) (Fig. 7B). These results reinforce that the degree of voltage-dependent
$\mathrm{Mg}^{2+}$ block of the current responses to NMDA is prominently reduced in developing PN neurons near postnatal day 15.

\section{Permeation of $\mathrm{Ca}^{2+}$ through NMDA receptor channels in the presence of $\mathbf{M g}^{2+}$}

A decrease in $\mathrm{Mg}^{2+}$ block would increase the $\mathrm{Ca}^{2+}$ entry particularly at the resting membrane potential. We examined permeation of $\mathrm{Ca}^{2+}$ through NMDA receptor channels that are relatively insensitive to $\mathrm{Mg}^{2+}$. Whole-cell recordings were made from PN neurons at P3-P4 $(n=8), \mathrm{P} 14-\mathrm{P} 15(n=8)$, and P28-P29 $(n=8)$. Ionophoretic applications of NMDA were performed to evoke $\mathrm{Ca}^{2+}$ currents in $\mathrm{PN}$ neurons that were perfused with a $\mathrm{Ca}^{2+}$ Ringer's solution in which $\mathrm{Na}^{+}$and $\mathrm{K}^{+}$were replaced with 


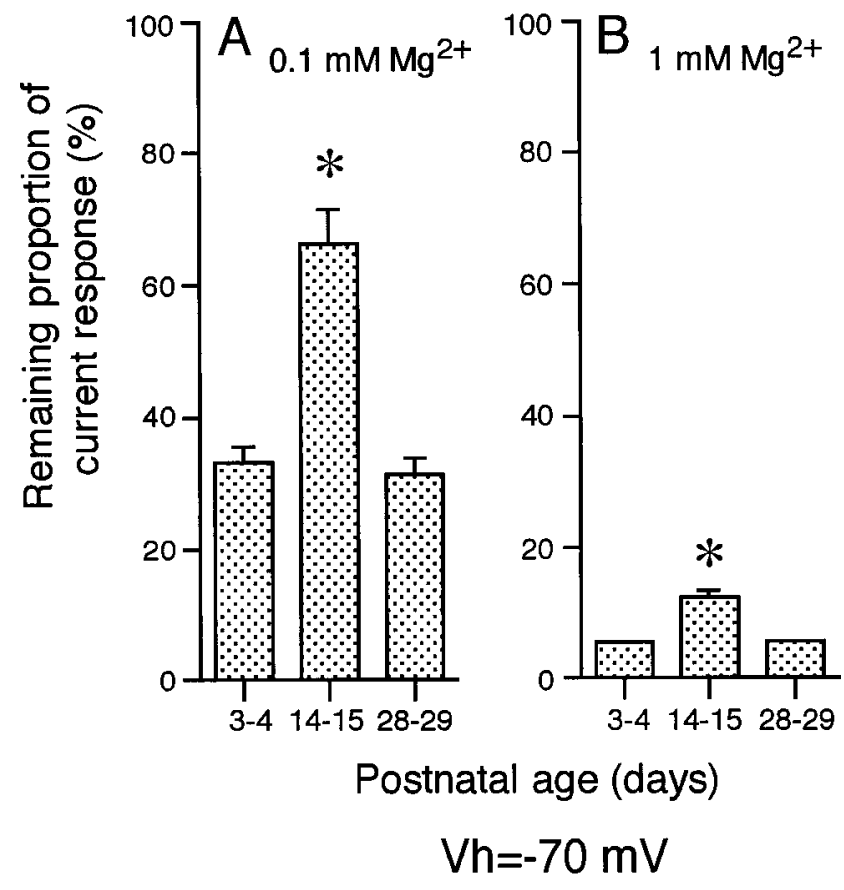

Figure 7. Changes in the $\mathrm{Mg}^{2+}$ block of current responses to NMDA in developing neurons in the pontine nucleus. Histograms show pooled data of peak amplitudes of current responses remaining after $\mathrm{Mg}^{2+}$ block relative to responses in a nominally $0 \mathrm{mM} \mathrm{Mg}^{2+}$ Ringer's solution (error bars represent SEM; each column, $n=12$ ). The data were obtained at $-70 \mathrm{mV}$ in the presence of $0.1 \mathrm{mM} \mathrm{Mg}^{2+}(A)$ and $1.0 \mathrm{mM} \mathrm{Mg}^{2+}(B)$ from neurons in the pontine nucleus at P3-P4, P14-P15, and P28-P29. The remaining proportions of current responses in the presence of 0.1 and 1.0 $\mathrm{mM} \mathrm{Mg}{ }^{2+}$ at P14-P15 are significantly larger than the corresponding values at P3-P4 and at P28-P29 (one-way ANOVA and Bonferroni/Dunn post hoc tests, $\left.{ }^{*} p<0.0001\right)$.

an impermeant cation $\mathrm{NMG}$ and $10 \mathrm{mM} \mathrm{Ca}^{2+}$ and $5 \mathrm{mM} \mathrm{Mg}^{2+}$ were added. When PN neurons were held at a more negative membrane potential $(-100 \mathrm{mV})$ to eliminate the currents through NMDA receptor channels that are sensitive to voltagedependent $\mathrm{Mg}^{2+}$ block, the amplitudes of NMDA-induced $\mathrm{Ca}^{2+}$ currents at P3-P4 and P28-P29 were very small (Fig. 8a,c), whereas substantial NMDA-induced $\mathrm{Ca}^{2+}$ currents were induced in PN neurons at P14-P15 (Fig. 8b). At a holding potential of $-100 \mathrm{mV}$, the amplitudes of $\mathrm{Ca}^{2+}$ currents at P14-P15 were significantly larger than those at P3-P4 and P28-P29 $(p<$ 0.0001) (Fig. 9). These results indicate that the NMDA channels that are relatively insensitive to $\mathrm{Mg}^{2+}$ in developing $\mathrm{PN}$ neurons near postnatal day 15 are permeable to $\mathrm{Ca}^{2+}$ at the resting membrane potential.

\section{In situ hybridization for NMDA receptor subunit mRNAs}

Prominent expression signals for the NR1 mRNA were already expressed in the pontine nucleus and also in other various brainstem nuclei at P1 and were observed at all developmental stages examined (Fig. 10A-E). Few specific signals for the NR2A mRNA were found in the pontine nucleus at P1. Specific signals for the NR2A mRNA appeared in the pontine nucleus at P7, the signal intensity increased gradually until P21, and the expression of NR2A mRNA in the pontine nucleus slightly decreased in adult rats (Fig. 10F-J). The NR2B mRNA was intensely expressed in the pontine nucleus and also in other various brainstem nuclei at P1. Then, the signal intensity in the pontine nucleus gradually decreased and was weak in adult rats (Fig. $10 \mathrm{~K}-\mathrm{O}$ ). Few specific signals for the NR2C mRNA were found in the pontine nucleus during the first week after birth (Fig. 10P,Q). Expression signals for the NR2C mRNA appeared in the pontine nucleus after P7; the signals were distinctly expressed in the pontine nucleus at P11 (data not shown), P14 (Fig. 10R), and also P21 (Fig. 10S). In adult rats, the NR2C mRNA was still expressed in the pontine nucleus (Fig. 10T). No specific signals for the NR2D mRNA were detected in the pontine nucleus at $\mathrm{P} 1$, whereas the signals were intensely expressed in many other brainstem nuclei (Fig. 10U). Slight expression signals for the NR2D mRNA were detected in the pontine nucleus at P7-P21, especially at P7, but the expression of NR2D mRNA in the pontine nucleus was generally weak at all developmental stages examined (Fig. 10U$Y)$. When the overall distribution patterns of NMDA receptor subunit mRNAs examined in other brainstem nuclei were applied to parasagittal or horizontal brainstem sections of developing and adult rats, they were generally in accordance with those reported by previous studies in rats and mice (Moriyoshi et al., 1991; Money et al., 1992; Watanabe et al., 1992, 1993; Akazawa et al., 1994).

The signals were almost completely abolished when the hybridization was performed in the presence of excess unlabeled oligonucleotides, which indicated the specificity of the present in situ hybridization.

\section{DISCUSSION}

The present in vivo NMDA injection study demonstrated that the pontine nucleus near postnatal day 15 was most susceptible to the toxicity of NMDA. Furthermore, the whole-cell recording study revealed that NMDA responses that are relatively insensitive to $\mathrm{Mg}^{2+}$ steadily increased in an age-dependent manner during the first two postnatal weeks, reached the maximal level near postnatal day 15, and then decreased after postnatal day 16. The whole-cell recording study also demonstrated that the NMDA responses that are relatively insensitive to $\mathrm{Mg}^{2+}$ induced $\mathrm{Ca}^{2+}$ entry at the resting membrane potential. In the excitotoxic hypothesis (Rothman and Olney, 1986; Choi, 1988; Siesjö and Bengtsson, 1989), large $\mathrm{Ca}^{2+}$ entry has been thought to trigger catastrophic enzymatic processes leading to irreversible neuronal injury. The NMDA receptor channels that easily permit $\mathrm{Ca}^{2+}$ entry at the resting membrane potential could play an important role in the development of neuronal death induced by NMDA toxicity. Therefore, the present results suggest that the susceptibility to NMDA neurotoxicity that is enhanced in the rat pontine nucleus near postnatal day 15 is mediated by the NMDA responses that are relatively insensitive to $\mathrm{Mg}^{2+}$. The present in situ hybridization study demonstrated that the expression signals for the NR2C mRNA in the pontine nucleus appeared after postnatal day 7 and were distinctly expressed at postnatal day 14 . This time course of the developmental change in the expression of the NR2C mRNA in the pontine nucleus until postnatal day 14 coincided with that of the developmental change in the NMDA responses that are relatively insensitive to $\mathrm{Mg}^{2+}$. Previous molecular biological studies have reported that the sensitivity of NMDA receptor channels to $\mathrm{Mg}^{2+}$ block is critically determined by the constituting NR2 subunits (Kutsuwada et al., 1992; Ishii et al., 1993; Money et al., 1994); the recombinant NR1-NR2C and NR1-NR2D channels show relatively weak sensitivity to $\mathrm{Mg}^{2+}$ block, whereas the recombinant NR1-NR2A and NR1-NR2B channels show strong sensitivity to $\mathrm{Mg}^{2+}$ block (Money et al., 1994). Thus, the developmental increase in the NMDA responses 
$\mathrm{Na}^{+}$free, $10 \mathrm{mM} \mathrm{Ca}^{2+}$

$a$

P3 $b$

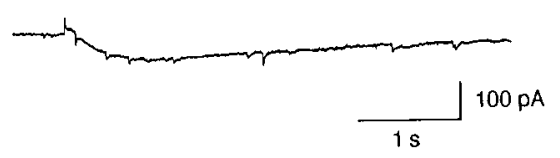

$c$

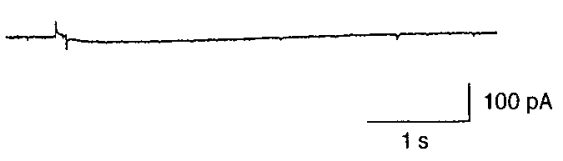

Figure 8. Permeation of $\mathrm{Ca}^{2+}$ through NMDA receptor channels in the presence of $\mathrm{Mg}^{2+}$ during postnatal development. Neurons in the pontine nucleus at $\mathrm{P} 3(a), \mathrm{P} 14(b)$, and $\mathrm{P} 28(c)$ were perfused with a Ca ${ }^{2+}$ Ringer's solution in which $\mathrm{Na}^{+}$and $\mathrm{K}^{+}$were replaced with an impermeant cation $\mathrm{NMG}$ and $10 \mathrm{mM} \mathrm{Ca}^{2+}$ and $5 \mathrm{mM} \mathrm{Mg}^{2+}$ were added. Ionophoretic applications of NMDA were performed to evoke current responses. Current responses at $-100 \mathrm{mV}$ are shown. Substantial NMDA-induced $\mathrm{Ca}^{2+}$ currents are shown at P14.

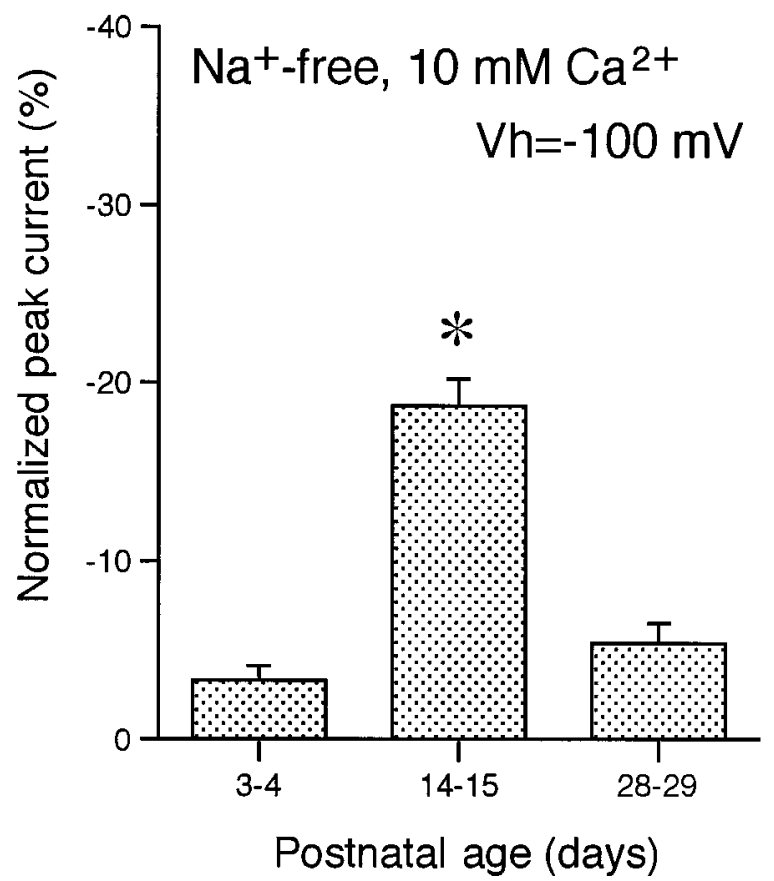

Figure 9. Changes in permeation of $\mathrm{Ca}^{2+}$ through NMDA receptor channels of developing neurons in the pontine nucleus at $-100 \mathrm{mV}$ in the presence of $\mathrm{Mg}^{2+}$. The responses were recorded from neurons in the pontine nucleus at P3-P4, P14-P15, and P28-P29. The amplitude of current responses was normalized to the mean value at $+50 \mathrm{mV}$ in each experiment. Histograms show pooled data of peak amplitudes of current responses to NMDA in a $\mathrm{Ca}^{2+}$ Ringer's solution. Error bars represent SEM (each column, $n=8$ ). The normalized peak amplitude of current responses to NMDA at P14-P15 is significantly larger than that at P3-P4 and at P28-P29 (one-way ANOVA and Bonferroni/Dunn post hoc tests, $\left.{ }^{*} p<0.0001\right)$.

that are relatively insensitive to $\mathrm{Mg}^{2+}$ in the pontine nucleus until postnatal day 14 may correlate with the increase in the expression of NR2C. Takahashi et al. (1996) have reported that $\mathrm{Mg}^{2+}$ block of NMDA receptor-mediated EPSCs decreases as the expression of the NR2C $(\epsilon 3)$ is predominantly in developing granule cells of the mouse cerebellum. The extent of the reduction in the sensitivity of NMDA receptors to $\mathrm{Mg}^{2+}$ block observed in the cerebellar granule cells is very similar to that observed in the present study. The present in situ hybridization study also demonstrated that the time course of the developmental change in the expression of the NR2C mRNA in the pontine nucleus after postnatal day 16 did not coincide with that of the developmental change in the NMDA responses that are relatively insensitive to $\mathrm{Mg}^{2+}$. The expression signals for the NR2C mRNA were still high in the pontine nucleus at postnatal day 21 and in adult rats, whereas the NMDA responses that are relatively insensitive to $\mathrm{Mg}^{2+}$ significantly decreased throughout the stages. This result suggests that factors other than NR2C expression reduce the $\mathrm{Mg}^{2+}$-insensitive NMDA responses and the susceptibility to NMDA-mediated neuronal injury in the pontine nucleus after postnatal day 16. It has been reported that native NMDA receptors might be assembled from more than two NR2 subunits. Wafford et al. (1993) have shown that the NR1, NR2A, and NR2C subunits preferentially coassemble in the same NMDA receptor complex when all three subunit cDNAs are present and also have demonstrated that the glutamate affinity of the receptors formed from $\mathrm{NR} 1+\mathrm{NR} 2 \mathrm{~A}+\mathrm{NR} 2 \mathrm{C}$ is lower than that of the receptors formed from NR1+NR2C. Incorporation of NR2A or other $\mathrm{Mg}^{2+}$ sensitive subunits into the NR1+NR2C receptors may occur progressively in the pontine nucleus after postnatal day 16 , and it might produce reductions in the $\mathrm{Mg}^{2+}$-insensitive NMDA responses and in the susceptibility to NMDA-mediated neuronal injury in spite of high expression of NR2C throughout the stages.

Changes in the neuronal susceptibility to NMDA toxicity have been observed in other developing brain regions. NMDA that was directly injected into the striatum at postnatal day 7 induced a maximal lesion involving the striatum and overlying neocortex, whereas the same concentration of NMDA did not induce any apparent lesion at postnatal days 1, 14, and 21 (McDonald et al., 1988; McDonald and Johnston, 1990). The expression of the NMDA receptor channels that are relatively insensitive to $\mathrm{Mg}^{2+}$ may underlie the enhancement of susceptibility to NMDA neurotoxicity in other developing brain regions. Indeed, in immature rat neocortical neurons, NMDA receptors have been reported to show a reduced $\mathrm{Mg}^{2+}$ block (Kato and Yoshimura, 1993). According to electrophysiological and histogenetic studies (Shimono et al., 1976; Hámori and Somogyi, 1983; Garthwaite and Brodbelt, 1989; D'Angelo et al., 1993), mossy fibers in the rat pontine nucleus begin to make contact with granule cells at postnatal day 10 , and the process of the contact is accelerated and reaches a peak at postnatal day 15 and is complete by postnatal day 21 . The time course of the development of mossy fiber-granule cell synaptic contacts coincides with that of the development of NMDA currents that are relatively insensitive to $\mathrm{Mg}^{2+}$. This coincidence proposes an idea that the NMDA receptor channels that are relatively insensitive to $\mathrm{Mg}^{2+}$ and easily permit $\mathrm{Ca}^{2+}$ entry at the resting membrane potential are essential for developing neurons to perform the neuronal differentiation and the establishment or elimination of synapses.

In the human brain, it is at $\sim 30$ weeks of gestation that mossy fibers make contact with granule cells (Rakic and Sidman, 1970; Sidman and Rakic, 1982). The NMDA receptor channels that are 

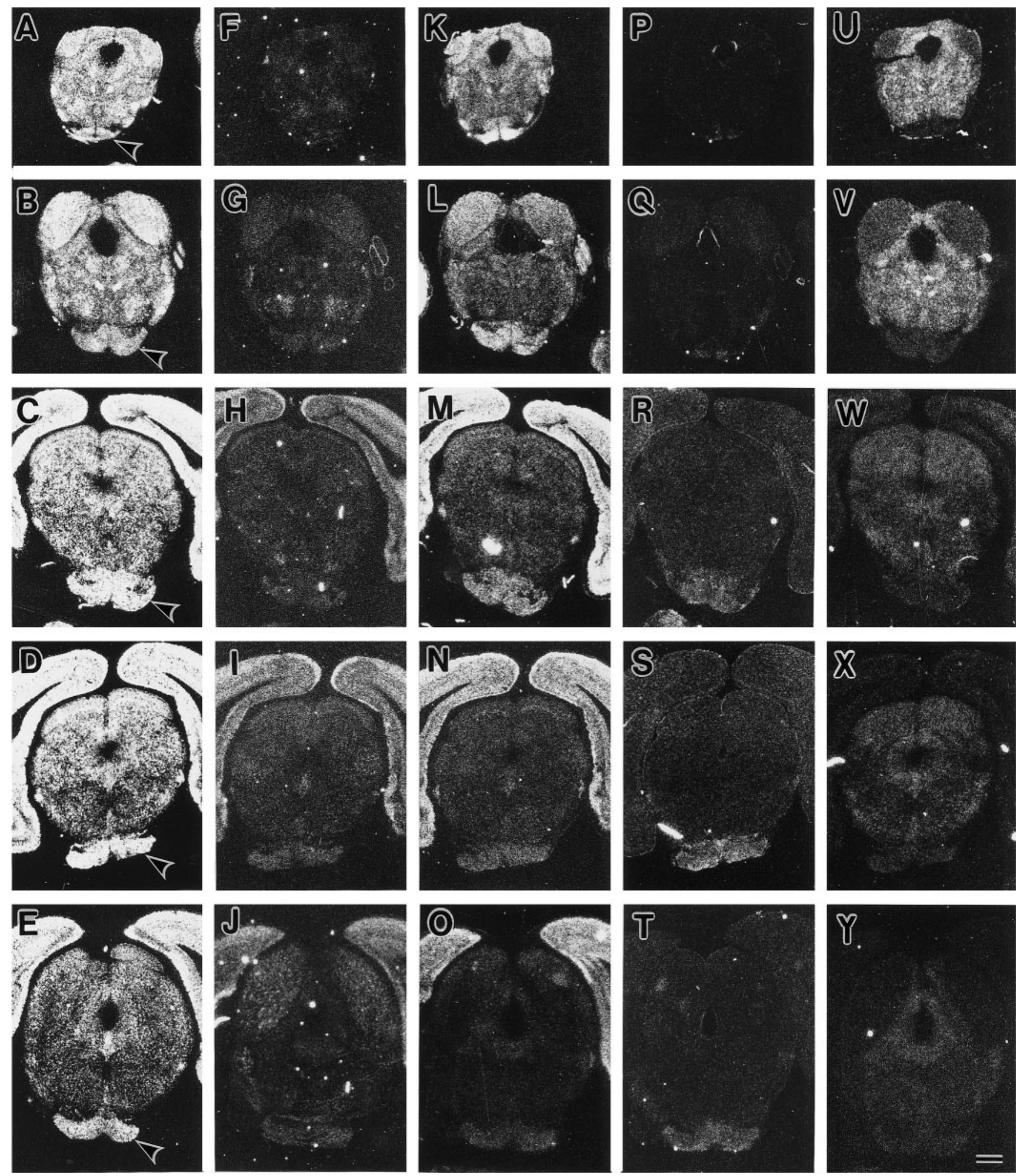

Figure 10. In situ hybridization showing the expression of mRNAs for the five NMDA receptor subunits (NR1, NR2A, NR2B, NR2C, and NR2D) in the developing rat pontine nucleus. $A-E$, NR1. $F-J$, NR2A. $K-O$, NR2B. $P-T$, NR2C. $U-Y$, NR2D. Antisense oligonucleotides labeled with ${ }^{35}$ S-dATP were hybridized to adjacent frontal sections at P1 $(A, F, K, P, U)$, at $\mathrm{P} 7(B, G, L, Q, V)$, at $\mathrm{P} 14(C, H, M, R, W)$, at $\mathrm{P} 21(D, I, N, S, X)$, and in the adult $(E, J, O, T, Y)$ in the same experiment. Arrowheads in $A-E$ indicate the pontine nucleus. Each set of developing brainstem sections was exposed to a single $\mathrm{x}$-ray film, from which photographs were directly printed at the same magnification. Scale bar, $1 \mathrm{~mm}$. 
relatively insensitive to $\mathrm{Mg}^{2+}$ may be expressed in the pontine nucleus of the human at the developing period. It is well known that glutamate is excessively released with no regional selectivity in the hypoxic-ischemic brain (Benveniste et al., 1984; Hagberg et al., 1985; Globus et al., 1991; Mitani et al., 1992, 1994b), whereas excessive increase in intracellular $\mathrm{Ca}^{2+}$ is selectively produced in vulnerable brain regions to hypoxia and ischemia (Mitani et al., 1990, 1994a, 1995). Therefore, the excessive increase in intracellular $\mathrm{Ca}^{2+}$ is thought to play a crucial role in the development of hypoxia- and ischemia-induced neuronal death (Choi, 1995; Mitani, 1996). If the NMDA receptor channels that are relatively insensitive to $\mathrm{Mg}^{2+}$ are expressed in the developing pontine nucleus of the human as mentioned above, the pontosubicular neuronal necrosis, which is found in the human brain during a developmental period between 30 weeks of gestation and the second postnatal month and often coexists with other forms of cerebral hypoxic and ischemic injuries, may be mediated by the NMDA receptor channels that are relatively insensitive to $\mathrm{Mg}^{2+}$.

\section{REFERENCES}

Akazawa C, Shigemoto R, Bessho Y, Nakanishi S, Mizuno N (1994) Differential expression of five $N$-methyl-D-aspartate receptor subunit mRNAs in the cerebellum of developing and adult rats. J Comp Neurol 347:150-160

Altman J (1972a) Postnatal development of the cerebellar cortex in the rat: I. The external germinal layer and the transitional molecular layer. J Comp Neurol 145:353-398.

Altman J (1972b) Postnatal development of the cerebellar cortex in the rat: II. Phases in the maturation of Purkinje cells and of the molecular layer. J Comp Neurol 145:399-464.

Benveniste H, Drejer J, Shousboe A, Diemer NH (1984) Elevation of the extracellular concentrations of glutamate and aspartate in the rat hippocampus during transient cerebral ischemia monitored by intracerebral microdialysis. J Neurochem 43:1369-1374.

Choi DW (1988) Calcium-mediated neurotoxicity: relationship to specific channel types and role in ischemic damage. Trends Neurosci 11:465-469.

Choi DW (1995) Calcium: still center-stage in hypoxic-ischemic neuronal death. Trends Neurosci 18:58-60.

Collingridge GL, Bliss TVP (1987) NMDA receptors: their role in longterm potentiation. Trends Neurosci 10:288-293.

D'Angelo E, Rossi P, Taglietti V (1993) Different proportions of $N$-methyl-D-aspartate and non- $N$-methyl-D-aspartate receptor currents at the mossy fibre-granule cell synapse of developing rat cerebellum. Neuroscience 53:121-130.

Edwards FA, Konnerth A, Sakmann B, Takahashi T (1989) A thin slice preparation for patch clamp recordings from neurones of the mammalian central nervous system. Pflügers Arch 414:600-612.

Farrant M, Feldmeyer D, Takahashi T, Cull-Candy SG (1994) NMDAreceptor channel diversity in the developing cerebellum. Nature 368:335-339.

Friede RL (1972) Ponto-subicular lesions in perinatal anoxia. Arch Pathol 94:343-354.

Garthwaite J, Brodbelt AR (1989) Synaptic activation of $N$-methyl-Daspartate and non- $N$-methyl-D-aspartate receptors in the mossy fibre pathway in adult and immature rat cerebellar slices. Neuroscience 29:401-412.

Globus MYT, Busto R, Martinez E, Valdés I, Dietrich WD, Ginsberg MD (1991) Comparative effect of transient global ischemia on extracellular levels of glutamate, glycine, and $\gamma$-aminobutyric acid in vulnerable and nonvulnerable brain regions in the rat. J Neurochem 57:470-478.

Hagberg H, Lehmann A, Sandberg M, Nyström B, Jacobson I, Hamberger A (1985) Ischemia-induced shift of inhibitory and excitatory aminoacids from intra- to extracellular compartments. J Cereb Blood Flow Metab 5:413-419.

Hámori J, Somogyi J (1983) Differentiation of cerebellar mossy fiber synapses in the rat: a quantitative electron microscope study. J Comp Neurol 220:365-377.

Hollmann M, Boulter J, Maron C, Beasley L, Sullivan J, Pecht G,
Heinemann S (1993) Zinc potentiates agonist-induced currents at certain splice variants of the NMDA receptor. Neuron 10:943-954.

Iino M, Ozawa S, Tsuzuki K (1990) Permeation of calcium through excitatory amino acid receptor channels in cultured rat hippocampal neurons. J Physiol (Lond) 424:151-165.

Ikeda K, Nagasawa M, Mori H, Araki K, Sakimura K, Watanabe M, Inoue Y, Mishina M (1992) Cloning and expression of the $\epsilon 4$ subunit of the NMDA receptor channel. FEBS Lett 313:34-38.

Ishii T, Moriyoshi K, Sugihara H, Sakurada H, Kadotani H, Yokoi M, Akazawa C, Shigemoto R, Mizuno N, Masu M, Nakanishi S (1993) Molecular characterization of the family of the $N$-methyl-D-aspartate receptor subunits. J Biol Chem 268:2836-2843.

Johnson JW, Ascher P (1987) Glycine potentiates the NMDA response in cultured mouse brain neurones. Nature 325:529-531.

Kato N, Yoshimura H (1993) Reduced $\mathrm{Mg}^{2+}$ block of $\mathrm{N}$-methyl-Daspartate receptor-mediated synaptic potentials in developing visual cortex. Proc Natl Acad Sci USA 90:7114-7118.

Komuro H, Rakic P (1993) Modulation of neuronal migration by NMDA receptors. Science 260:95-97.

Kutsuwada T, Kashiwabuchi N, Mori H, Sakimura K, Kushiya E, Araki K, Meguro H, Masaki H, Kumanishi T, Arakawa M, Mishina M (1992) Molecular diversity of the NMDA receptor channel. Nature 358:36-41.

Manabe T, Araki I, Takahashi T, Kuno M (1991) Membrane currents recorded from sexually dimorphic motoneurones of the bulbocavernosus muscle in neonatal rats. J Physiol (Lond) 440:419-435.

Mayer ML, Westbrook GL (1987) Permeation and block of $N$-methyl-Daspartic acid receptor channels by divalent cations in mouse cultured central neurones. J Physiol (Lond) 394:501-527.

Mayer ML, Westbrook GL, Guthrie RB (1984) Voltage-dependent block by $\mathrm{Mg}^{2+}$ of NMDA responses in spinal cord neurones. Nature 309:261-263.

McDonald JW, Johnston MV (1990) Physiological and pathophysiological roles of excitatory amino acids during central nervous system development. Brain Res Rev 15:41-70.

McDonald JW, Silverstein FS, Johnston MV (1988) Neurotoxicity of $N$-methyl-D-aspartate is markedly enhanced in developing rat central nervous system. Brain Res 459:200-203.

Meguro H, Mori H, Araki K, Kushiya E, Kutsuwada T, Yamazaki M, Kumanishi T, Arakawa M, Sakimura K, Mishina M (1992) Functional characterization of a heteromeric NMDA receptor channel expressed from cloned cDNAs. Nature 357:70-74.

Mitani A (1996) Roles of glutamate in ischemia-induced delayed neuronal death. In: The hippocampus: functions and clinical relevance (Kato N, ed), pp 87-94. Amsterdam: Elsevier.

Mitani A, Kadoya F, Kataoka K (1990) Distribution of hypoxia-induced calcium accumulation in gerbil hippocampal slice. Neurosci Lett 120:42-45.

Mitani A, Andou Y, Kataoka K (1992) Selective vulnerability of hippocampal CA1 neurons cannot be explained in terms of an increase in glutamate concentration during ischemia in the gerbil: brain microdialysis study. Neuroscience 48:307-313.

Mitani A, Takeyasu S, Yanase H, Nakamura Y, Kataoka K (1994a) Changes in intracellular $\mathrm{Ca}^{2+}$ and energy levels during in vitro ischemia in the gerbil hippocampal slice. J Neurochem 62:626-634.

Mitani A, Andou Y, Matsuda S, Arai T, Sakanaka M, Kataoka K (1994b) Origin of ischemia-induced glutamate efflux in the CA1 field of the gerbil hippocampus: an in vivo brain microdialysis study. J Neurochem 63:2152-2164.

Mitani A, Yanase H, Namba S, Shudo M, Kataoka K (1995) In vitro ischemia-induced intracellular $\mathrm{Ca}^{2+}$ elevation in cerebellar slices: a comparative study with the values found in hippocampal slices. Acta Neuropathol (Berl) 89:2-7.

Money H, Sprengel R, Schoepfer R, Herb A, Higuchi M, Lomeli H, Burnashev N, Sakmann B, Seeburg PH (1992) Heteromeric NMDA receptors: molecular and functional distinction of subtypes. Science 256:1217-1221.

Money H, Burnashev N, Laurie DJ, Sakmann B, Seeburg PH (1994) Developmental and regional expression in the rat brain and functional properties of four NMDA receptors. Neuron 12:529-540.

Moriyoshi K, Masu M, Ishii T, Shigemoto R, Mizuno N, Nakanishi S (1991) Molecular cloning and characterization of the rat NMDA receptor. Nature 354:31-37.

Nowak L, Bregestovski P, Ascher P, Herbet A, Prochiantz A (1984) Magnesium gates glutamate-activated channels in mouse central neurones. Nature 307:462-465. 
Rabacchi S, Bailly Y, Delhaye-Bouchaud N, Mariani J (1992) Involvement of the $N$-methyl-D-aspartate (NMDA) receptor in synapse elimination during cerebellar development. Science 256:1823-1825.

Rakic P, Sidman RL (1970) Histogenesis of cortical layers in human cerebellum, particularly the lamina dissecans. J Comp Neurol 139:473-500.

Rothman SM, Olney JW (1986) Glutamate and the pathophysiology of hypoxic-ischemic brain damage. Ann Neurol 19:105-111.

Sakimura K, Kutsuwada T, Ito I, Manabe T, Takayama C, Kushiya E, Yagi T, Aizawa S, Inoue Y, Sugiyama H, Mishina M (1995) Reduced hippocampal LTP and spatial learning in mice lacking NMDA receptor $\epsilon 1$ subunit. Nature 373:151-155.

Schmued L, Kyriakidis K, Heimer L (1990) In vivo anterograde and retrograde axonal transport of the fluorescent rhodamine-dextranamine, Fluoro-Ruby, within the CNS. Brain Res 526:127-134.

Shimono T, Nosaka S, Sasaki K (1976) Electrophysiological study on the postnatal development of neuronal mechanisms in the rat cerebellar cortex. Brain Res 108:279-294.

Sidman RL, Rakic P (1982) Development of the human central nervous system. In: Histology and histopathology of the nervous system (Haymaker W, Adams RD, eds), pp 3-145. Springfield, IL: Thomas.

Siesjö BK, Bengtsson F (1989) Calcium fluxes, calcium antagonists, and calcium-related pathology in brain ischemia, hypoglycemia, and spreading depression: a unifying hypothesis. J Cereb Blood Flow Metab 9:127-140.
Sohma O, Mito T, Mizuguchi M, Takashima S (1995) The prenatal age critical for the development of the pontosubicular necrosis. Acta Neuropathol (Berl) 90:7-10.

Takahashi T, Feldmeyer D, Suzuki N, Onodera K, Cull-Candy SG, Sakimura K, Mishina M (1996) Functional correlation of NMDA receptor $\epsilon$ subunits expression with the properties of single-channel and synaptic currents in the developing cerebellum. J Neurosci 16:4376-4382.

Torvik A, Skullerud K, Andersen SN, Hurum J, Mæhlen J (1992) Affection of the hippocampal granule cells in pontosubicular neuron necrosis. Acta Neuropathol (Berl) 83:535-537.

Wafford KA, Bain CJ, Le Bourdelles B, Whiting PJ, Kemp JA (1993) Preferential co-assembly of recombinant NMDA receptors composed of three different subunits. NeuroReport 4:1347-1349.

Watanabe M, Inoue Y, Sakimura K, Mishina M (1992) Developmental changes in distribution of NMDA receptor channel subunit mRNAs. NeuroReport 3:1138-1140.

Watanabe M, Inoue Y, Sakimura K, Mishina M (1993) Distinct distributions of five NMDA receptor channel subunit mRNAs in the forebrain. J Comp Neurol 338:377-390.

Yamazaki M, Mori H, Araki K, Mori KJ, Mishina M (1992) Cloning, expression and modulation of a mouse NMDA receptor subunit. FEBS Lett 300:39-45. 